\title{
REKONSTRUKSI HUKUM PERKAWINAN BEDA AGAMA BERBASIS HAK ASASI MANUSIA DI INDONESIA
}

\author{
Moh. Zeinudin \\ Oos Ariyanto ${ }^{(2)}$ \\ ${ }^{(1)}$ Dosen Program Studi Magister Hukum \\ Pascasarjana Universitas Wiraraja \\ ${ }^{(2)}$ Mahasiswa Magister Ilmu Hukum Universitas \\ Brawijaya \\ zain.fh@wiraraja.ac.id ${ }^{(1)}$ \\ oosariyanto@student.ub.ac.id ${ }^{(2)}$
}

\begin{abstract}
ABSTRAK
Tidak seperti perkawinan campuran beda kewarganegaraan, perkawinan beda agama ternyata masih belum diatur secara jelas dan tegas dalam Undang-Undang Nomor 16 Tahun 2019 Tentang Perubahan atas Undang-Undang Nomor 1 Tahun 1974 Tentang Perkawinan. Kondisi pengaturan yang demikian, berpotensi melanjutkan perdebatan panjang tak pernah usai sepanjang dinamika politik hukum perkawinan di Indonesia. Bahkan hingga saat ini, berbagai hasil penelitian menunjukkan bahwa perkawinan beda agama masih terjadi dalam berbagai bentuk praktiknya di Indonesia dengan memanfaatkan celah-celah hukum dan banyaknya interpretasi tentang boleh tidaknya perkawinan beda agama. Atikel ini ditulis dalam rangka mengkaji persoalan perkawinan beda agama yang berbasis nilai-nilai Hak Asasi Manusia (HAM) yang menjamin kepastian hukum, yaitu terpenuhinya hak moral dan hak legal yang menjunjung tinggi martabat kemanusiaan berdasarkan Pancasila dan Konstitusi Negara Indonesia.
\end{abstract}

Kata Kunci : Rekonstruksi Hukum, Perkawinan dan Hak Asasi Manusia 


\section{A. PENDAHULUAN}

Polemik perkawinan beda agama terus bergulir sepanjang sejarah politik hukum perkawinan di Indonesia. Bahkan hingga saat ini, perkawinan beda agama masih juga belum diatur secara jelas dan tegas dalam Undang-Undang Nomor 16 Tahun 2019 Tentang Perubahan atas Undang-Undang Nomor 1 Tahun 1974 Tentang Perkawinan, yang merupakan kodifikasi hukum perkawinan nasional terbaru yang berlaku di Indonesia. ${ }^{1}$ Pengaturan hukum yang demikian, akan terus melahirkan beragam interpretasi hukum dan yurisprudensi tentang hukum perkawinan beda agama, baik yang sifatnya mengabulkan, maupun yang sifatnya menolak permohonan perkawinan beda agama. Bahkan faktanya, hingga saat ini perkawinan beda agama terus terjadi dalam berbagai bentuk praktiknya di Indonesia dengan memanfaatkan celah-celah hukum dan keragaman penafsiran tentang syarat sahnya perkawinan menurut hukum agama sebagaimana diatur dalam pasal 2 ayat (1) Undang-Undang Perkawinan. ${ }^{2}$ Bahkan hingga pascaputusan Mahkamah Konstitusi (MK) Nomor 68/PUU-XII/2014 yang menolak permohonan beda agama untuk

${ }^{1}$ Dahwal, Sirman, Hukum Perkawinan Beda Agama Di Indonesia, Bandung, Mandar Maju, 2016, hal. 74

${ }^{2}$ Sri Wahyuni, Kontroversi Perkawinan Beda Agama di Indonesia, Volume 14, No. 2, Desember 2014, Jurnal Ar Risalah, hal. 296 seluruhnya, perkawinan beda agama masih terus terjadi di Indonesia.

Perkawinan adalah hak setiap orang, siapa saja dapat melakukan perkawinan. Sehingga pada hakikatnya setiap orang berhak menikah dengan pilihannnya sendiri dan dilaksanakan sesuai dengan kepercayaan agamanya sebagaimana yang sudah dicantumkan dalam undang-undang perkawinan Pasal 2 ayat (1) Perkawinan adalah sah, apabila dilakukan menurut hukum masingmasing agamanya dan kepercayaannya itu. Tapi, apabila salah satu pihak yang akan menikah beda agama, maka hal inilah yang menjadi problem di Indonesia. Karena di Indonesia sendiri belum ada hukum yang mengatur tentang perkawinan beda agama.Yang banyak terjadi, perkawinan beda agama ini dapat dilakukan di Indonesia dengan jalur salah satu pihak menundukkan dirinya ke agama yang disepakati. Misalnya agama laki-lakinya islam dan agama perempuannya kristen. Sehingga untuk dapat dilakukan perkawinan di Indonesia maka perempuan tersebut tunduk ke agama yang laki-laki atau sebaliknya. Tentunya orang-orang yang tidak melaksanakan perkawinan karena beda agama, kemungkinan akan beranggapan bahwa hak untuk melakukan perkawinan sesuai pilihannya tidak terpenuhi. 
Berdasarkan narasi di atas, mengkaji ulang hukum perkawinan beda agama yang berbasis nilai-nilai Hak Asasi Manusia (HAM) diharapkan dapat memberi perspektif yang lebih luas tentang bagaimana bentuk penghormatan terhadap martabat manusia dan kemanusian, yang sejatinya tidak diskriminatif terhadap perbedaan agama, sebab semua warga negara, bersamaan kedudukannya di depan hukum memiliki hak yang sama untuk memenuhi haknya sebagai manusia dan warga Negara dalam bingkai konstitusi dan HAM.

\section{B. PEMBAHASAN}

Sejak Amandemen UndangUndang Dasar 1945, kedudukan hak asasi manusia di Indonesia menjadi sangat penting dalam kehidupan berbangsa. Hal ini terlihat dengan luasnya pengaturan terkait hak asasi manusia dan pengelompokkannya khusus dalam satu bab tersendiri. Selain UUD 1945, sebelumnya terdapat Ketetapan MPR Nomor XVII/MPR/1998 tentang Hak Asasi Manusia dan Undang-Undang Nomor 39 Tahun 1999 tentang Hak Asasi Manusia telah memberikan landasan yang kuat mengenai penghormatan terhadap hak asasi manusia di Indonesia.

Mengkaji Hak Asasi Manusia (HAM) secara komprehensif dalam kaitannya dengan konstruksi hukum perkawinan beda agama, bukanlah persoalan yang sederhana. Secara umum, akan tercakup didalamnya dimensi nilai, dimensi konsep, dan dimensi perundangundangannya. Apalagi jika dikaitkan juga dengan kepastian hukum, selain harus dapat dipertanggung jawabkan secara epistemologi khususnya berkaitan dengan makna "kepastian" itu sendiri, juga akan bersinggungan dengan keseimbangan antara keadilan dan kemanfaatan sebagai bagian dari tujuan hukum.

Tujuan hukum yang diikhtiarkan dapat mengakomodir keseimbangan aspek keadilan, kepastian, dan kemanfaatan pada akhirnya harus diselenggarakan berdasarkan penghormatan terhadap HAM. Sedangkan pada sisi lain, agar legitimasi HAM menjadi kuat dan terjamin juga memerlukan wadah hukum dalam bentuk perundang-undangan. HAM yang memberikan landasan terhadap kepastian hukum, dan kepastian hukum jaminan terhadap HAM. $^{3}$ Dalam konteks melangsungkan perkawinan akan mendapat makna kepastian hukum terselenggaranya hak dan kewajiban berdasarkan HAM. Perspektif HAM secara umum yang meliputi tataran nilai, konsep, dan perundang-undangan, pada dasarnya merupakan suatu konsep yang

\footnotetext{
${ }^{3}$ Slamet Marta Wardaya, Hak Asasi Manusia. Hakekat, Konsep, dan Implikasinya Dalam Perspektif Hukum dan Masyarakat, ed. H. Muladi, Bandung: PT. Rafika Aditama, 2005, hal. 243
} 


\section{IURNAL JENDELA HUKUM}

ISSN Cetak E Online : 2355-5831/ 2355-9934

seharusnya dapat berjalan secara konsisten, harmonis, sistematis, dan sinkron. HAM dalam kerangka demikian ditengarai akan dapat memberikan kontribusi pada tataran praktis dengan meminimalisir berbagai pandangan subyektif yang cenderung dikotomis. HAM dilihat dari sisi nilai berarti harus dapat dipertanggung jawabkan secara moral atau lebih dikenal sebagai bernilai moral, berarti harus dapat dipertanggung jawabkan berdasarkan parameter tertentu atau lebih dikenal sebagai bernorma moral, dan pada akhirnya HAM harus dapat dipertanggung jawabkan untuk dapat menjadi pelindung sesuatu yang tidak dapat disubstitusikan yang lain yakni martabat manusia. HAM bernilai moral mengandung makna bahwa kebebasan, tanggung jawab, nurani, dan kewajiban harus diletakkan secara mutlak, otonom, dan proporsional. Suatu keputusan yang bernilai moral, dengan demikian masyarakat manusia dalam keadaan bebas tanpa tekanan dari siapapun. Kebebasan yang dimiliki harus dipertanggung jawabkan secara pribadi dan berdasarkan kebenaran suara nurani yang wajib ditaati.

Nilai-nilai moral yang hendak dibangun sebagai landasan HAM tersebut pada akhirnya harus memiliki parameter atau ukuran-ukuran tertentu. Parameter yang tercermin di dalam norma moral pada intinya menuntut adanya obyektivitas dan universalitas yang berujung pada martabat manusia sebagai parameter tertinggi dan terpenting. ${ }^{4}$ Dimaksudkan memiliki obyektivitas terdapat dua catatan yang perlu diperhatikan. Pertama, bahwa suatu ukuran yang bersifat subyektif tidak berarti mengadakan penyangkalan terhadap obyektivitas norma moral. Pengakuan terhadap norma moral dikarenakan kewajiban untuk ciptaan subyek. Kedua,adanya sifat subyektif tidak berarti peniadaan kebebasan, justru sebaliknya norma moral selalu mengandaikan kebebasan. Obyektivitas norma moral tidak boleh sebagai paksaan dengan menyingkirkan kebebasan. Berkaitan dengan universalitas norma moral, umum sepakat bahwa perilaku tidak jujur suatu kelompok misalnya, akan mendapat penilaian tidak jujur pula dari kelompok masyarakat lainnya.

Martabat manusia sebagai norma tertinggi dan terpenting dalam norma moral yang akan menjadi dasar HAM, sudah sepatutnya dapat dipahami secara memadai. Untuk memahami yang dimaksudkan dengan martabat, dapat dibandingkan atau dibedakan dengan harga. Harga selalu bermakna namun pada prinsipnya dapat disubstitusi. Sedangkan martabat adalah sesuatu yang unik dan pada prinsipnya tidak dapat disetarakan atau di substitusikan.

Imanuel kant mengartikan isi

\footnotetext{
${ }^{4}$ Slamet Marta Wardaya, Ibid.
} 


\section{IURNAL JENDELA HUKUM}

ISSN Cetak E Online : 2355-5831/ 2355-9934

moral sebagai martabat. ${ }^{5}$ Kewajiban penghormatan terhadap martabat manusia merupakan suatu bentuk perintah yang tidak dapat ditawar. Dalam tatapan konsep, HAM dipahami berdasarkan aspek hak dan kewajiban yang meliputi hak moral dan hak legal, serta kewajiban moral dan kewajiban legal. Pemikiran hak dalam artian modern baru muncul pada akhir abad 17 atau permulaan abad 18. Hak dalam artian modern dapat dicirikan dengan kebebasan manusia terlepas dari ikatan hukum obyektif. Kenyataan perkembangan ini muncul sebagai akibat dari keinsafan manusia dalam menempatkan manusia sebagai makhluk bermartabat yang bebas dan otonom. Sedangkan tradisi pemikiran tentang kewajiban mendahului pemikiran tentang hak. Kenyataan ini dapat dibuktikan berdasarkan banyak ajaran yang berkonotasi kewajiban terhadap Tuhan, Agama, Raja, Negara atau kelompokkelompok tertentu. Fakta menunjukkan, bahwa sesungguhnya sejak dulu terdapat korelasi antara hak dan kewajiban. Setiap kewajiban seseorang selalu berkaitan dengan hak orang lain.

Pemahaman terhadap hak dan kewajiban secara memadai akan meliputi pemahaman terhadap hak dan kewajiban baik secara moral maupun legal. Hak legal

${ }^{5}$ Friedrich, C.J., Immanuel Kant's Moral and Political Writings, NewYork: Random House, 1949, hal. 155 adalah hak berdasarkan atas hukum dan sepenuhnya berdasarkan prinsip-prinsip hukum. Sedangkan hak moral adalah hak yang hanya berdasarkan prinsip etis. Hak moral belum tentu hak legal, meskipun banyak hak moral yang serentak adalah juga hak legal. Meskipun antara hak moral dan hak legal berbeda, namun idealnya hak legal adalah juga hak moral. Peraturan hukum yang ideal apabila merupakan hasil endapan moralitas yang baik. Demi efektivitas sebaiknya hak moral diberi legitimasi hak legal. Hak moral akan memiliki kedudukan kuat apabila dilindungi status hukum yang kuat.

Berkenaan dengan kewajiban moral dan kewajiban legal, akan mendapat gambaran yang jelas dengan mengandaikan pembagian kewajiban atas "kewajiban sempurna" dan "kewajiban tidak sempurna". Kewajiban sempurna berarti selalu terkait dengan hak orang lain, dan sebaliknya kewajiban tidak sempurna berarti tidak terkait dengan hak orang lain. Kewajiban sempurna selalu mendasarkan diri pada keadilan, sehingga orang memiliki kewajiban jika orang lain berhak menuntut agar sesuatu diberikan kepadanya. Sedangkan kewajiban tidak sempurna berarti tidak berdasarkan atas keadilan tetapi semata-mata hanya memiliki alasan moral yang lain, misalnya berbuat baik atau murah hati 


\section{JURNAL JENDELA HUKUM}

ISSN Cetak E Online : 2355-5831/ 2355-9934

terhadap orang lain yang memang berarti sekaligus menghormati membutuhkan.

kemahadaulatan Allah". Dengan

HAM dalam tataran konsep ditinjau demikian, sangat tidak mungkin berdasarkan aspek kemasyarakatan akan menghormati Allah dan dalam waktu memunculkan konsep individualisme, konsep kolektivisme (mekanistis dan organistis), dan konsep personalisme. Konsep individualisme akan menekankan pada kebebasan pribadi manusia seluasluasnya dan tidak seorangpun boleh mengganggunya. Konsep kolektivisme Mekanistis akan menekankan pada kolektivitas yang berkembang dan digerakkan oleh kekuatan mekanis di luar kehendak individu. Sedangkan konsep kolektivisme organistis mengandung menekankan masyarakat sebagai suatu organisme hidup yang tediri dari individuindividu yang digerakan oleh kekuatan organis diluar kehendak individu. Sedangkan konsep personalisme menekankan bahwa pribadi manusia tidak dapat dipandang sebagai individu berdaulat atau kolektivisme. Pribadi manusia harus dipandang sebagai personal sosial, dibina oleh masyarakat, hidup terikat oleh masyarakat, mengendalikan hak asasi dan hak-hak lainnya, yang penggunaannya harus diselaraskan dengan kepentingan umum.

Pemahaman secara konsep atas HAM berdasarkan Martabat Manusia Ciptaan Allah adalah berdasarkan gambaran: "menghormati martabat manusia yang bersamaan memperkosa martabat manusia. Setiap upaya mempertentangkan antara hormat terhadap Allah dan hormat terhadap manusia merupakan tindakan yang tidak dapat dibenarkan.

Semua manusia sebagai manusia pada hakikatnya adalah sama di hadapan Allah, tanpa membedakan latar belakang agama, suku, kekayaan, atau jenis kelamin. Dengan demikian, adanya diskriminasi berdasarkan perbedaan bangsa, warna kulit, jenis kelamin, bahasa, agama, keyakinan politik, pendapat, kelahiran atau kedudukan memiliki makna sebagai melanggar martabat manusia.

Karena di hadapan Allah, semua manusia adalah sama derajatnya, maka tidak ada orang atau kelompok manapaun yang begitu saja berhak menguasai seseorang. Ini berarti setiap kekuasaan manusia atas manusia harus memiliki legitimasi. Bahwa tidak ada wewenang mutlak manusia terhadap manusia lainnya, berarti tidak ada wewenang di dunia untuk mewajibkan sesuatu melawan suara hati. Dalam suara hatinya, manusia selalu menyadari bahwa ia hanya bertanggung jawab mutlak terhadap Allah. 


\section{IURNAL JENDELA HUKUM}

ISSN Cetak E Online : 2355-5831/ 2355-9934

Kekhususan manusia terletak pada akal budi dan kemauannya yang mampu mendengarkan suara hati dalam kondisi bebas. Martabat manusia menuntut bahwa setiap orang tanpa kecuali dihormati hakhak asasinya. Berdasarkan kenyataan bahwa Allah telah menunjukkan kerahimannya terhadap manusia, memunculkan suatu norma dasar bahwa: "bahwa apabila dapat dicegah, manusia tidak pernah boleh dibiarkan menderita". Menghormati martabat manusia secara konkret berarti menjamin perlindungan HAM. Oleh karena itu, muncul kecenderungan kuat dewasa ini dengan menekankan bahwa HAM wajib dilindungi secara hukum. Kewajiban asasi manusia terhadap masyarakat perlu diimbangi dengan jaminan hak-hak asasinya. Pelanggaran terhadap HAM merupakan perlakuan yang tidak sesuai dengan martabat manusia. Kodrat manusia sebagai ciptaan Allah telah mengimplikasikan bahwa penghormatan terhadap HAM berarti hormat terhadap Allah pula. Kalau kita memang ber-Tuhan Allah, kita harus menjunjung tinggi HAM, sebab HAM karya Allah sendiri.

Dalam hubungannya dengan kepastian, secara epistemologis terdapat tiga jenis kepastian, yaitu Certitudo Metaphysica yang bersifat mutlak, Certitudo Physica yang bersifat hipotesis, dan Certitudo Moralis yang bersifat manusiawi. Hubungan antara ketiga jenis dan sifat kepastian tersebut adalah "perbandingan" dan "keterjalinan".

Berdasarkan perbandingan, maka yang dilihat adalah kadar konstan dengan urutan tertinggi pada Certituo Metaphysica dan Certitudi Moralis. Sedangkan berdasarkan keterjalinan adalah, adanya kepastian dasar dan dasar kepastian sebagai legitimasi bagi kepastian pengembangan ilmu pengetahuan bagi manusia dan lingkungan. Adanya keterjalinan ketiga jenis kepastian tersebut membawa konsekuensi hilangnya kekuatiran membuat pernyataan secara keliru, karena manusia tahu bahwa dirinya tidak keliru. Sedangkan dalam hubungannya dengan kepastian hukum, terlebih dahulu harus disinggung fungsi dan tujuan hukum. Fungsi dan tujuan hukum sebenarnya sudah terkandung di dalam batasan pengertian atau definisi tentang hukum. Hukum yang didefinisikan sebagai perangkat kaidah dan asas yang mengatur kehidupan manusia dan masyarakat, dapat disimpulkan bahwa salah satu fungsi terpenting adalah tercapainya keteraturan. Konsekuensi dari keteraturan tersebut adalah bahwa dalam kehidupan harus terdapat kepastian. Keteraturan yang berisikan kepastian, didalam konteks kepentingan penjagaan keamanan pada gilirannya disebut ketertiban. 
Meskipun makna keadilan dapat bermacam-macam karena adanya perbedaan sistem nilai, namun hukum positif tetap harus berdasarkan keadilan. Keruntuhan hukum akan terjadi manakala masyarakat pendukungnya merasakan suatu ketidakadilan dalam pengaturan hukum. Konstruksi demikian secara logis menghasilkan kesimpulan bahwa ketidakadilan akan mengganggu ketertiban, dan seterusnya karena ketertiban terganggu, maka akan terganggu pula kepastian hukum.

Pandangan logis antara keadilan, ketertiban, dan kepastian sebagai mana dikemukakan di atas, terkadang akan menemui kesukaran dalam realitanya. Oleh karenanya muncul kecenderungan untuk membedakan antara fungsi dan tujuan hukum. Hukum dalam rangka menjamin keteraturan, kepastian, dan ketertiban harus dipandang bukan sebagai tujuan akhir namun hanya merupakan fungsi. Sedangkan tujuan hukum selalu berkaitan dengan tujuan akhir dalam kehidupan masyarakat dan pada akhirnya bernuara pada keadilan.

Secara konvensional dikemukakan bahwa tujuan hukum sekaligus akan meliputi keadilan, kemanfaatan, dan kepastian. Tujuan hukum yang menitik beratkan kepada keadilan beranjak dari teori etis, dan tujuan hukum yang menitik beratkan kepada kemanfaatan beranjak dari teori utilitis. Sedangkan tujuan hukum yang menitik beratkan kepada kepastian beranjak dari teori yuridis dogmatik atau positivisme hukum.

Didalam perkembangan kemudian, ketiga bagian tujuan hukum secara konvensional tersebut sering disebut sebagai ajaran prioritas baku. Berdasarkan relitas dalam masyarakat, penerapan ajaran konvensional atau relitas baku seringkali menghadapi kendala. Atau dalam redaksi lain, spesifikasi hukum dengan tujuan-tujuan spesifik, seperti antara hukum pidana dan perdata, atau hukum materiil dan hukum formil telah menjadikan persoalan semakin rumit.

Terhadap persoalan spesifik di dalam masyarakat tersebut, maka ajaran prioritas baku memberi solusi sebagai berikut: prioritas pertama diberikan kepada keadilan, disusul oleh kemanfaatan, dan terakhir kepastian. Urutan tersebut tidak dapat dirubah sehingga ketika memutuskan suatu perkara, maka prioritas-prioritas keadilan, kemanfaatan, dan kepastian harus ditempatkan secara berurutan. Sedangkan ajaran prioritas kasuistis memberi makna keadilan, kemanfaatan, dan kepastian harus ditempatkan sesuai kasus yang dihadapai.

Sampai pada poin ini, penulis berpendapat, bahwa kepastian hukum berdasarkan HAM yang bersendi utama 
pada martabat manusia sebagai norma terpenting, harus diletakkan secara proporsional terhadap manusia yang akan melangsungkan perkawinan. Perkawinan berlangsung dengan mengedepankan kepastian hukum hak dan kewajiban individu manusia yang bermartabat sebagai dasar pijakan HAM.

Bahwa setiap penerbitan hukum perkawinan dalam bentuk perundangundangan dalam suatu negara, dan melibatkan unsur agama di dalamnya, maka terlebih dahulu akan terjadi proses pemaknaan terhadap agama itu sendiri. Nilai-nilai agama akan diberi makna antara sosiologis dan ideologis. Makna agama denghan sifat sisiologis akan terbagi dalam dua kategori, yakni kategori fungsional dan kategori substansial. ${ }^{6}$ Dengan kategori fungsional maka agama menjadi wahana interpretatif yang akan membantu manusia untuk membuka misteri tabir alam semesta. Dengan kategori substansial, maka agama menjadi wahana yang berkaitan dengan supranatural atau dunia transenden. Sedangkan makna agama dengan sifat ideologis, berati agama akan dipakai sebagai unsur atau wahana untuk merebut dan mempertahankan kekuasaan atau kewenangan. Proses tarik menarik antara

6 Abdurrahman, Hukum Perkawinan Beda Agama (Dalam Perspektif Hukum Dan Agama), https://suduthukum.com/2015/01/hukumperkawinan-beda-agama-dalam_20.html diakses tanggal 07 September 2021 agama yang diberi makna sosiologis dan ideologis, akan terus berlangsung seturut keinginan masyarakat pendukung yang multidimensional.

Dengan demikian, menjadi jelas bahwa corak hukum perkawinan yang melibatkan unsur agama di dalamnya, cenderung akan menghadapi persoalan yang tidak sederhana, tergantung dari bobot penempatan makna agama itu sendiri, apakah lebih cenderung ke "sosiologis fungsional", "sosiologis substansial" atau "ideologis". Menjadi persoalan dalam hal agama dimasukkan sebagai salah satu unsur pembentukan hukum negara adalah, tidak ada jaminan perlindungan perlakuan adil dan tidak diskriminatif terhadap agama lain, manakala agama tertentu secara eksklusif dijadikan ideologi dan sumber hukum negara.

Proses terbentuknya UndangUndang Nomor 1 Tahun 1974 Tentang Perkawinan yang diwarnai oleh silang pendapat antar anggota masyarakat, pada satu sisi menunjukkan tingkat atau kadar kepedulian atau kepentingan masyarakat akan hal tersebut. Bahwa pada kenyataannya, salah satu klasula yang dianggap kontroversial dalam pembahasan adalah berkaitan dengan sahnya perkawinan, antara berdasarkan 
agama dan cukup dicatatkan saja. ${ }^{7}$ Nomor 1 Tahun 1974 Tentang

Persoalan keabsahaan suatu perkawinan berdasarkan dua pilihan tersebut menjadi semakin kontroversial, karena akan membuka peluang selebar-lebarnya terhadap disahkannya perkawinan beda agama. $^{8}$

Perseturuan yang semakin sengit menyangkut keabsahaan perkawinan, pada akhirnya dirumuskan secara "tidak memuaskan" dan "tidak menyelesaikan persoalan". Artinya, persoalan perkawinan beda agama tidak diatur secara tegas, atau dapat dikatakan tidak memiliki kepastian hukum. ${ }^{9}$ Adanya pasal yang menyatakan bahwa perkawinan sah adalah menurut hukum agama masing-masing, ternyata dalam pasal yang lain dibuka kemungkinan perkawinan adalah sah menurut catatan saja, asalkan dilangsungkan tidak di wilayah hukum Indonesia. Kontradiksi antar pasal dalam satu perudang-undangan telah menunjukkan adanya sikap kompromistis yang secara formal sangat tidak mempedulikan nilai-nilai metode pembuatan perundang-undangan secara benar, yakni terpenuhinya asas konsistensi, harmonisasi, sistemasi, dan sinkronisasi.

Persoalan penting lain yang sekiranya perlu mendapat perhatian adalah makna dari pasal 6 ayat 1 Undang-Undang

\footnotetext{
7 Sudarsono, Hukum Perkawinan Nasional, Jakarta: Rineka Cipta, 2005, hal. 75

${ }^{8}$ Abdurrahman, Ibid.,

${ }^{9}$ Abdurrahman, Op. Cit.
}

Perkawinan yang menegaskan, bahwa: “ Perkawinan harus didasarkan atas persetujuan kedua calon mempelai". Kata persetujuan mengandung makna yang substansial didalam hukum keperdataan. Secara normatif, persyaratan akan sahnya suatu persetujuan telah diletakan dalam pasal 1320 KUH Perdata, yaitu terpenuhinya: (1) Kesepakatan; (2) kecakapan; (3) obyek tertentu; (4) dan tidak bertentangan dengan hukum, kesusilaan dan kepentingan umum. Pasal tersebut secara doktrinal dapat diklasifikasikan menjadi dua bagian. Syarat nomor 1 dan 2 disebut sebagai syarat subyektif dan syarat nomer 3 dan 4 disebut sebagai syarat obyektif. Dalam suatu persetujuan, apabila syarat subyektif tidak dipenuhi berarti dapat dibatalkan. Sedangkan bila syarat obyektif tidak terpenuhi berarti batal demi hukum. Kenyataan ini mengandung makna bahwa kemungkinan terdapat pihak yang tidak cakap menurut hukum atau dibuatnya suatu pesetujuan secara tidak bebas. $^{10}$

Ditinjau secara materiil, UndangUndang Nomor. 1 Tahun 1974 Tentang Perkawinan yang tidak memberikan kepastian hukum secara memadai terhadap pihak-pihak yang akan

${ }^{10}$ R. Subekti, Hukum Perjanjian, Jakarta, Intermasa, Cet. Ke-18, 2001, Hlm. 19-21 


\section{IURNAL JENDELA HUKUM}

\section{ISSN Cetak E Online : 2355-5831/ 2355-9934}

melangsungkan perkawinan beda agama, sudah dapat dikategorikan sebagai kurang menghargai HAM. ${ }^{11}$ Seharusnya hak dan kewajiban individu manusia berdasarkan parameter martabat manusia sebagai norma tertinggi dan terpenting sebagai landasan HAM mendapat perlindungan secara pasti berupa kepastian hukum. Perkawinan beda agama yang mendapat legitimasi agama dan moral sebagai suatu anugerah dari Allah, ternyata dikebiri atas nama legitimasi legal yang mengabaikan martabat manusia sebagai landasan utama HAM.

Sehingga perkawinan beda agama ini, sudah semestinya mendapat perhatian dari pemerintah dengan dikeluarkan pengaturan hukum yang baru. Karena kasus perkawinan beda agama ini bukan hal baru, sudah bayak yang melakukan perkawinan beda agama bahkan seorang puclic figur ada yang melaksanakan perkawinan beda agama, entah menundukkan diri pada salah satu agama atau menikah diluar negeri yang memperbolehkan perkawinan beda agama dapat dilaksanakan. Tetapi pada perubahan undang-undang perkawinan yang baru sama sekali tidak menyinggung perihal perkawinan beda agama, maka polemik perkawinan beda agama ini akan menjadi perbincangan dan dianggap melanggar hak orang yang melakukan perkawinan beda

11 Hazairin, Tinjauan Mengenai UndangUndang Nomor 1 Tahun 1974 Tentang Perkawinan, Jakarta, Tinta Mas, 1986, hal. 44 agama. sehingga terciptalah kepastian hukum yang diharapkan diterima oleh masyarakat. Segingga cita-cita hukum untuk masyarakatkan masyarakat tercipta dengan adanya kepastian hukum.

\section{KESIMPULAN}

Dari narasi tentang hak asasi manusia dan kepastian hukum yang cukup panjang di atas, maka sejatinya rekonstruksi hukum perkawinan kedepan dapat memberikan kepastian hukum terhadap kemungkinan terlaksananya hak moral dan hak legal dalam melaksanakan perkawinan beda agama sebagai bukti nyata terwujudnya penghormatan terhadap martabat kemanusiaan berdasarkan hak asasi manusia, Pancasila, dan konstitusi, yang tidak diskrimanatif karena perbedaan agama. Sebab setiap warga negara bersamaaan kedudukannya di depan hukum, memiliki hak yang sama sebagai warga negara untuk memperoleh haknya sebagai manusia, sebagai warga negara, dan juga sebagai pribadi yang bebas beragama dan berkeyakinan, termasuk di dalamnya hak untuk melaksanakan perkawinan beda agama berdasarkan pilihan kemanusiaannya, dan sekaligus juga berdasarkan pilihan kebebasan beragama dan berkeyakinan pada dirinya. 


\section{Buku}

\section{DAFTAR BACAAN}

Dahwal, Sirman, Hukum Perkawinan Beda Agama Di Indonesia, Bandung, Mandar Maju, 2016

Friedrich, C.J., Immanuel Kant's Moral and Political Writings, NewYork: Random House, 1949

Hazairin, Tinjauan Mengenai UndangUndang Nomor 1 Tahun 1974 Tentang Perkawinan, Jakarta, Tinta Mas, 1986

R. Subekti, Hukum Perjanjian, Jakarta, Intermasa, Cet. Ke-18, 2001

Slamet Marta Wardaya, Hak Asasi Manusia. Hakekat, Konsep, dan Implikasinya Dalam Perspektif Hukum dan Masyarakat, ed. $\mathrm{H}$. Muladi, Bandung: PT. Rafika Aditama, 2005

Sudarsono, Hukum Perkawinan Nasional, Jakarta: Rineka Cipta, 2005

\section{Jurnal}

Sri Wahyuni, Kontroversi Perkawinan Beda Agama di Indonesia, Volume 14, Jurnal Ar Risalah, 2014.

\section{Peraturan Perundang-Undangan}

Undang-undang dasar 1945

undang-undang nomor 1 tahun 1974 tentang perkawinan

Undang-undang nomor 16 tahun 2019 tentang perubahan atas undangundang nomor 1 tahun 1974 tentang perkawinan

\section{Putusan pengadilan}

Putusan Mahkamah Konstitusi (MK) Nomor 68/PUU-XII/2014 tentang perkawinan beda agama dan kepercayaan.

\section{Laman}

Abdurrahman, Hukum Perkawinan Beda Agama (Dalam Perspektif Hukum Dan Agama), https://suduthukum.com/2015/01/huk um-perkawinan-beda-agamadalam_20.html 